\title{
GCU
}

Glasgow Caledonian

University

University for the Common Good

\section{Measuring evapotranspiration using an eddy covariance system over the Albany Thicket of the Eastern Cape, South Africa}

\author{
Gwate, O.; Mantel, Sukhmani K.; Palmer, Anthony R.; Gibson, Lesley A.
}

Published in:

Proc. SPIE 9998, Remote Sensing for Agriculture, Ecosystems, and Hydrology XVIII

DOI:

$10.1117 / 12.2245426$

Publication date:

2016

\section{Document Version}

Author accepted manuscript

Link to publication in ResearchOnline

Citation for published version (Harvard):

Gwate, O, Mantel, SK, Palmer, AR \& Gibson, LA 2016, Measuring evapotranspiration using an eddy covariance system over the Albany Thicket of the Eastern Cape, South Africa. in CMU Neale \& A Maltese (eds), Proc. SPIE 9998, Remote Sensing for Agriculture, Ecosystems, and Hydrology XVIII. vol. 9998, SPIE, Remote Sensing for Agriculture, Ecosystems, and Hydrology XVIII, Edinburgh, United Kingdom, 26/09/16.

https://doi.org/10.1117/12.2245426

\section{General rights}

Copyright and moral rights for the publications made accessible in the public portal are retained by the authors and/or other copyright owners and it is a condition of accessing publications that users recognise and abide by the legal requirements associated with these rights.

Take down policy

If you believe that this document breaches copyright please view our takedown policy at https://edshare.gcu.ac.uk/id/eprint/5179 for details

of how to contact us. 


\title{
Measuring evapotranspiration using an eddy covariance system over the Albany Thicket of the Eastern Cape, South Africa
}

\author{
O. Gwate*a, Sukhmani K. Mantel ${ }^{\mathrm{a}}$, Anthony R. Palmer ${ }^{\mathrm{b}}$, Lesley A. Gibson ${ }^{\mathrm{c}}$ \\ ${ }^{a}$ Institute for Water Research, Rhodes University South Africa, ${ }^{\mathrm{b}}$ Agricultural Research Council- \\ Animal Production Institute, South Africa, ${ }^{\mathrm{c}}$ Department of Construction and Surveying, Glasgow \\ Caledonian University, (Scotland, United Kingdom)
}

\begin{abstract}
Determining water and carbon fluxes over a vegetated surface is important in a context of global environmental changes and the fluxes help in understanding ecosystem functioning. Pursuant to this, the study measured evapotranspiration (ET) using an eddy covariance (EC) system installed over an intact example of the Albany Thicket (AT) vegetation in the Eastern Cape, South Africa. Environmental constraints to ET were also assessed by examining the response of ET to biotic and abiotic factors. The EC system comprised of an open path Infrared Gas Analyser and Sonic anemometer and an attendant weather station to measure bi-meteorological variables. Post processing of eddy covariance data was conducted using EddyPro software. Quality assessment of fluxes was also performed and rejected and missing data were filled using the method of mean diurnal variations (MDV). Much of the variation in ET was accounted for by the leaf area index (LAI, $\mathrm{p}<0.001,41 \%$ ) and soil moisture content (SWC, $\mathrm{p}<0.001,32 \%)$. Total measured ET during the experiment was greater than total rainfall received owing to the high water storage capacity of the vegetation and the possibility of vegetation accessing ground water. Most of the net radiation was consumed by sensible heat flux and this means that ET in the area is essentially water limited since abundant energy was available to drive turbulent transfers of energy. Understanding the environmental constraints to ET is crucial in predicting the ecosystem response to environmental forces such as climate change.
\end{abstract}

Keywords: Albany Thicket biome, data quality assessment, eddy covariance system, EddyPro software, energy fluxes evapotranspiration

\section{INTRODUCTION}

Evapotranspiration (ET) or latent heat flux (LE) is the combined loss of water vapour from plants and from surfaces ${ }^{1}$. Energy is required to break the strong bonds that hold water molecules together as a liquid and when those bonds break, the individual water molecules may enter the surrounding atmosphere as vapour ${ }^{2}$. However, there has to be sufficient wind and favourable vapour pressure deficit (VPD) to aid the transfer of the molecules from the water source to the atmosphere. It has been established that globally over two-thirds of the total precipitation over the continents is returned to the atmosphere as evapotranspiration, making it the largest single component of the terrestrial hydrological cycle after precipitation $^{3-8}$. In a context of global environmental changes associated with climate change, many parts of the world are increasingly experiencing water scarcity. Therefore, accurate measurement of the components of the hydrological cycle is crucial in order to understand water balance at a site and catchment scale for improved water resources management $^{7,9}$.

ET is one of the components of the catchment water budget that can provide key insights into the performance of land cover and land use activities. Consequently, ET controls the large-scale distribution of plant communities, primary production and is a vital process linking the hydrological cycle with other biogeochemical processes ${ }^{2,10}$. Plant water use efficiency (WUE) is the ratio of the rates of net $\mathrm{CO}_{2}$ assimilation (biomass) to transpiration ${ }^{11}$. The greater the WUE, the more carbon is fixed per unit water lost, thereby improving the chance of vegetation survival in drier environments or under drought ${ }^{2}$. Through links between stomatal conductance, carbon exchange, and WUE, plant ET serves as a regula- 
tor of key ecosystem processes. Various thicket vegetation formations are found in Africa, Madagascar, Asia, Australia and the Americas ${ }^{12}$ and such ecoregions are presumed to have very high water use efficiency. The Albany Thicket (AT) biome in South Africa provides an interesting ecosystem to evaluate dynamics in ET. Although the rainfall is low and erratic, the AT of South Africa is associated with high biomass and biodiversity ${ }^{12}$. This high tolerance of moisture deficits is linked to high water storage capacity of such vegetation, sclerophylly, Crassulacean Acid Metabolism (CAM) photosynthesis and succulence reported in such environments ${ }^{13-15}$. These characteristics of the biome exacerbate the complexity associated with understanding water use in such ecosystems. In South Africa research on the AT biome has mainly focused on carbon sequestration within the broader context of the Clean Development Mechanism, the distribution of particular species and the infiltration and runoff dynamics ${ }^{13,16,17}$. Therefore, little attention has been given to water use dynamics of the biome and this paper will contribute to that direction.

ET is a biophysical process that is strongly controlled by biotic and abiotic factors. For example, plants regulate the opening and closing of their stomata to minimize water loss, yet maximize $\mathrm{CO}_{2}$ absorption for photosynthesis ${ }^{1}$. Biotic controls of ET are related to canopy development and ecophysiological properties of plants such as stomata density, stomatal conductance or resistance, phenological stage of the canopy ${ }^{18}$ and rooting dynamics. Abiotic factors are connected to climatic factors such as precipitation, solar radiation, available energy and VPD. The complex interaction between these factors results in the variation of the pattern and magnitude of ET across environmental gradients. Wang et al. ${ }^{19}$ found that soil moisture/ precipitation was the main driver of ET in a Mongolian steppe and that the relationship between ET and VPD was complex. The same research observed that at high soil moisture, ET was marginally positively coupled to VPD while during periods of high water deficits, a negative correlation prevailed. On the other hand, biotic factors as represented by the LAI have been found to be linearly related to and accounted for much variation in ET ${ }^{17,19}{ }^{20}$. Therefore, it will be interesting to evaluate the water and energy fluxes in a physiognomically different biome characterised by AT vegetation to establish if there is any convergence in the behaviour of the land-atmosphere system. We hypothesize that biotic factors related to the behaviour of stomata are likely to play a crucial role in regulating flux exchanges between the land and atmosphere systems in the AT owing to the evolutionary convergent characteristics of the biome. Understanding main factors controlling ET is vital in marginal lands within the broader purview of global change and the need for sustainable management of natural resources such as water.

Land surface ET is one of the least understood and difficult to measure ecohydrological process. Consequently, a number of approaches have been developed to measure ET. Recent developments in technology have reduced uncertainties associated with the measurement of fluxes between the land-atmosphere systems. One of the most dependable and direct methods of measuring ET is the Eddy Covariance (EC) method ${ }^{21}{ }^{22}$. The theory of eddy covariance is based on the premise that the fluxes of water vapour and heat within the surface layer are nearly constant with height on relatively flat land, homogenous vegetation and under turbulent conditions. If these basic assumptions are met, the flux of LE and sensible heat $(\mathrm{H})$ can be calculated using the eddy covariance equation ${ }^{23}$ :

$$
\begin{aligned}
& L E=L_{v} \overline{\rho_{v}^{\prime} w^{\prime}} \\
& H=\rho_{a} C_{p} \overline{T^{\prime} w^{\prime}}
\end{aligned}
$$

where: $L E$ is the latent heat flux, $L_{v}$ is the latent heat flux of evaporation, $\rho^{\prime}{ }_{v}$ is the instantaneous deviation of the water density from the mean, $w^{\prime}$ is the instantaneous deviation of the vertical wind component from the mean, $H$ is sensible heat flux, $\rho_{a}$ is the density of air, $C_{p}$ is heat capacity of air at constant pressure, $T^{\prime}$ is the instantaneous deviation of air temperature from the mean.

The theory of eddy covariance is fraught with many assumptions which may not be fulfilled in the real world ${ }^{22,24}$. In addition, a number of errors such as time delays, frequency response and Path averaging errors are bound to occur in the application of the EC system ${ }^{22}$. Therefore, it is imperative to implement requisite corrections in order to reduce uncertainties in fluxes calculated. This study aims at understanding the land-atmosphere energy and water vapour exchanges over the AT vegetation using an eddy covariance system. Sustainable ecosystem management requires improved understanding of ET since it partly influences overall ecosystem productivity. 


\section{MATERIAL AND METHODS}

\subsection{Experimental site}

The AT biome covers about $16942 \mathrm{~km}^{2}$ of the country and is recognised as a biodiversity hotspot characterised by succulents, deciduous and semi-deciduous woody shrubs and dwarf shrubs, geophytes, annuals and grasses ${ }^{12}$. There is a rich diversity of life in terms of the understorey which comprises dwarf succulent shrubs and forbs, which arechieflyCrassulaceae and Aizoaceae. There is also rich diversity of perennial grasses such as Panicum maximum, P. deustum and Eragrostis species. A suitable patch of land to install the EC station was found at the eZulu Game Reserve, a privately-owned trophy hunting property that contains several thousand hectares of intact AT vegetation. The eddy covariance site was selected as it contains a large representative example of is intact AT dominated by Portulacaria afra and woody shrubs such as Pappea capensis and Euclea undulata on the prevailing wind side, with the mean height of $P$. afra of about $1 \mathrm{~m}$ in the theoretical footprint. The site has been un-grazed by domestic livestock since about 1996 and is currently under light wildlife stocking. Modelled annual pan evaporation is about $1963.9 \mathrm{~mm}$ while long-term mean annual rainfall is around $493.7 \mathrm{~mm}^{25}$ ). The area has a bimodal rainfall pattern, with mean long-term monthly maxima around OctoberNovember and in March. Average relative humidity is about $63 \%$ and the mean annual air temperature is around $25^{\circ} \mathrm{C}$. The area is underlain by sandstone and shale and altitude is $554 \mathrm{~m}$ asl and average slope was $3.6 \%$. The study site is located about $70 \mathrm{~km}$ from Grahamstown, Eastern Cape, South Africa (33 01' 08.929" S 26 04' 47.860" E).

\subsection{Instruments}

The instruments at the site include an eddy covariance (EC) system and a scientific grade automatic weather station. An Integrated CO2/H2O Open-Path Gas Analyzer and 3D Sonic Anemometer (IRGASON, Campbell Scientific Inc., Logan, Utah, USA) was installed on $9^{\text {th }}$ of October 2015. The eddy covariance system comprises an Integrated CO2/H2O OpenPath Gas Analyzer and 3D Sonic Anemometer (IRGASON, Campbell Scientific Inc., Logan, Utah, USA) which was installed on $9^{\text {th }}$ October 2015. An IRGASON is an in-situ, open-path, mid-infrared absorption gas analyser integrated with a three-dimensional sonic anemometer ${ }^{26}$. The gas analyser provides measurements of absolute densities of carbon dioxide and water vapour, while the sonic anemometer measures orthogonal wind components. The IRGASON is connected to the EC100 electronics, which synchronizes gas and wind data for the calculation of fluxes using the eddycovariance method $^{25}$. The EC100 electronics also uses inputs from a temperature thermistor probe and a barometer. The EC100 was then connected to a CR3000 (Campbell Scientific Inc., Logan, Utah, USA) data logger for recording the data.

The IRGASON was installed at a height of $2.65 \mathrm{~m}$ above the ground and the average vegetation height was $1 \mathrm{~m}$. A shielded (R.M. Young 41303-5A 6-Plate Solar Radiation Shield) temperature and relative humidity probe (HC2S3, Campbell Scientific Inc., Logan, Utah, USA) is installed so that it measures temperature at the same height as the sample volume of the IRGASON in order to measure air that had similar characteristics. Both the IRGASON and the temperature probe are connected to the EC100. Further, a fast response fine wire thermocouple (FW05: 0.0005 in /0.0127 mm, Campbell Scientific Inc., Logan, Utah, USA) is placed between the upper and lower arms of the IRGASON. Other biometeorological sensors installed included soil heat flux, volumetric soil water content (SWC), air and soil temperature probes. The soil heat flux $(\mathrm{G})$ is measured using four soil heat flux plates (HFP01, Campbell Scientific Inc., Logan, Utah, USA). The plates were placed at a depth of $80 \mathrm{~mm}$ below the soil surface. A system of parallel soil thermocouple probes (TCAV) are installed at depths of 20 and $60 \mathrm{~mm}$ to measure soil temperature. A soil thermocouple probe measures temperature at four locations, or junctions, each consisting of a type $\mathrm{E}$ thermocouple wire (chromel-constantan) that is enclosed within a stainless steel tube ${ }^{26}$. The thermocouple works in conjunction with the soil heat flux plate to calculate the heat flux at the surface of the soil. Volumetric soil water content (CS616, Campbell Scientific Inc., Logan, Utah, USA) was measured in the upper $60 \mathrm{~mm}$ of the soil. The installation of the heat flux plates, the soil temperature thermocouples and the water content reflectometer was done following instructions provided by ${ }^{26}$. The net radiation is measured using a net radiometer (Kipp \& Zonen, Netherlands). Table 1 presents the details of the instrumentation at the site. 
Table 1. Summary of instruments at the eZulu EC station

\begin{tabular}{|l|l|}
\hline Bio-meteorplogical variable & Instrument \\
\hline Net radiation $\left(\mathrm{W} \mathrm{m}^{-2}\right)$ & $\begin{array}{l}\text { Two net radiometers (NR-lite2, (Kipp \& Zonen, Nether- } \\
\text { lands }\end{array}$ \\
\hline Temperature and Relative humidity $(\%)$ & $\begin{array}{l}\text { HC2S3 Temperature and relative humidity Probe (Camp- } \\
\text { bell Scientific Inc., Logan, Utah, USA) }\end{array}$ \\
\hline Soil heat flux $\left(\mathrm{W} \mathrm{m}^{-2}\right)$ & $\begin{array}{l}\text { 4x soil heat plate (HFP01, Campbell Scientific Inc., Lo- } \\
\text { gan, Utah, USA) }\end{array}$ \\
\hline Air temperature $\left({ }^{\circ} \mathrm{C}\right)$ & $\begin{array}{l}\text { 2x Averaging soil thermocouples probe (TCAV, Campbell } \\
\text { Scientific Inc., Logan, Utah, USA) }\end{array}$ \\
\hline Volumetric soil water content (ratio) & $\begin{array}{l}\text { Water content reflectometer (CS616, Campbell Scientific } \\
\text { Inc., Logan, Utah, USA) }\end{array}$ \\
\hline Wind speed $\left(\mathrm{m} \mathrm{s}^{-1}\right)$ and direction (degrees) & IRGASON \\
\hline
\end{tabular}

Bio-meteorological probes are also connected to a CR3000 data logger (Campbell Scientific Inc., Logan, Utah, USA) for data recording. Data are saved onto a 2 GB compact flash memory card with the capacity to store up to six weeks of high frequency $(10 \mathrm{~Hz})$ data. The EC system is powered by two solar panels (SDT800 - 12V 80W Solar Module) that charge four 100 AmpHour deep cycle batteries (Deltec - SMF 1250 High Cycle).

\subsection{Data analysis}

Data were downloaded from the eddy covariance system and sorted for further analysis in EddyPro 6.0 (https://www.licor.com/env/products/eddy_covariance/eddypro.html) software. All raw $10 \mathrm{~Hz}$ data were firstly processed into half-hourly averages using LoggerNet (4.3) software (Campbell Scientific Inc., Logan, Utah, USA). Post processing included axis rotation for tilt correction was implemented using double rotation and the linear detrending method was applied to remove turbulent fluctuations. Time lag compensation was implemented using covariance maximization with default. Statistical tests for raw data screening, such as spike removal, amplitude resolution, drops outs, absolute limits, discontinuities, time lags, skewness and kurtoisis, steadiness of horizontal wind, angle of attack, were implemented following Vickers and Mahrt ${ }^{27}$. Random uncertainty estimation was implemented as described by Finkelstein and $\mathrm{Sim}^{28}$. The method described by ${ }^{29}$ was used to filter out data that failed statistical tests. This method is based on the steady state and integral turbulence characteristic tests and uses the values $(0,1$ and 2$)$ as an overall quality flag with fluxes flagged 2 not used in ET computation. Rejected and missing data were filled using the interpolation based method of mean diurnal variations (MDV) ${ }^{30}$. The EC footprint was estimated using the method of ${ }^{31}$. The WebbPearman-Leunning (WPL) correction was not implemented since the IRGASON internally corrects for density fluctuations.

The shortened energy balance equation is essentially a function of net radiation (Rn), latent heat flux (LE), sensible heat flux $(\mathrm{H})$ and soil heat flux $(\mathrm{G})$. It is expressed as:

$R n=L E+H+G$ 
The shortened energy balance equation ignores advection as well as physically and biochemically (photosynthctically) stored heat flux densities in the canopy as they are considered negligible compared to the other energy balance components ${ }^{32}$. One of the criterion for flux data quality is energy balance closure. Ideally the sum of latent and sensible heat energy would be equal to available energy $(R n-G)$. Therefore, model II simple linear regression using the Standard Major Axis (SMA) method was used to evaluate the site energy balance by plotting the sum of LE and $H(L E+H)$ against available energy $(R n-G)$. The SMA was considered suitable since it can handle errors and uncertainties in $\mathrm{x}$ and y axis variables ${ }^{33}$. In addition, the closure ratio was also assessed and is expressed as follows:

Closure ratio $=\frac{\sum(L E+H)}{\sum(R n-G)}$

SMA was also implemented to investigate the relationship between ET and environmental factors (VPD, LAI, SWC, Rn and available energy.

\subsection{Flux data quality}

\section{RESULTS}

The overall data availability and quality of micrometeorological data is presented in Figure. 1. The majority of missing data $(18 \%)$ failed the quality control or quality assessment (QC/QA) protocols while about $5 \%$ was missing due to system/ logging failure. Therefore, availability of relatively good quality data was at about $77 \%$. This percentage availability of data was high enough and adaptable for long-term analysis of evapotranspiration trends.

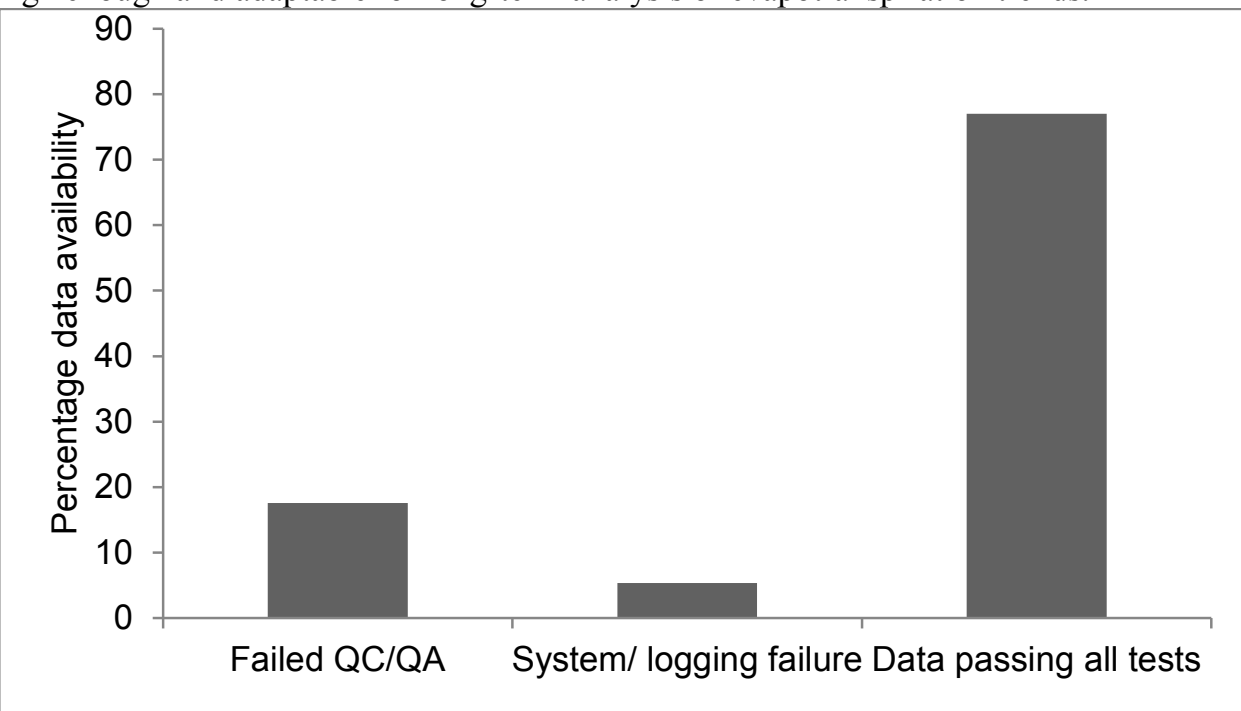

Figure 1. Data availability and quality of the EC data at eZulu station.

In order to ensure that all requisite spectral frequencies were captured, the water flux was plotted against the natural frequency. The plots were done over many different days and at different time periods. Our data passed the ogive test ${ }^{22}$ on the 30 minute averaging period since the integrated flux approached a constant value at low frequencies (Fig. 2). 


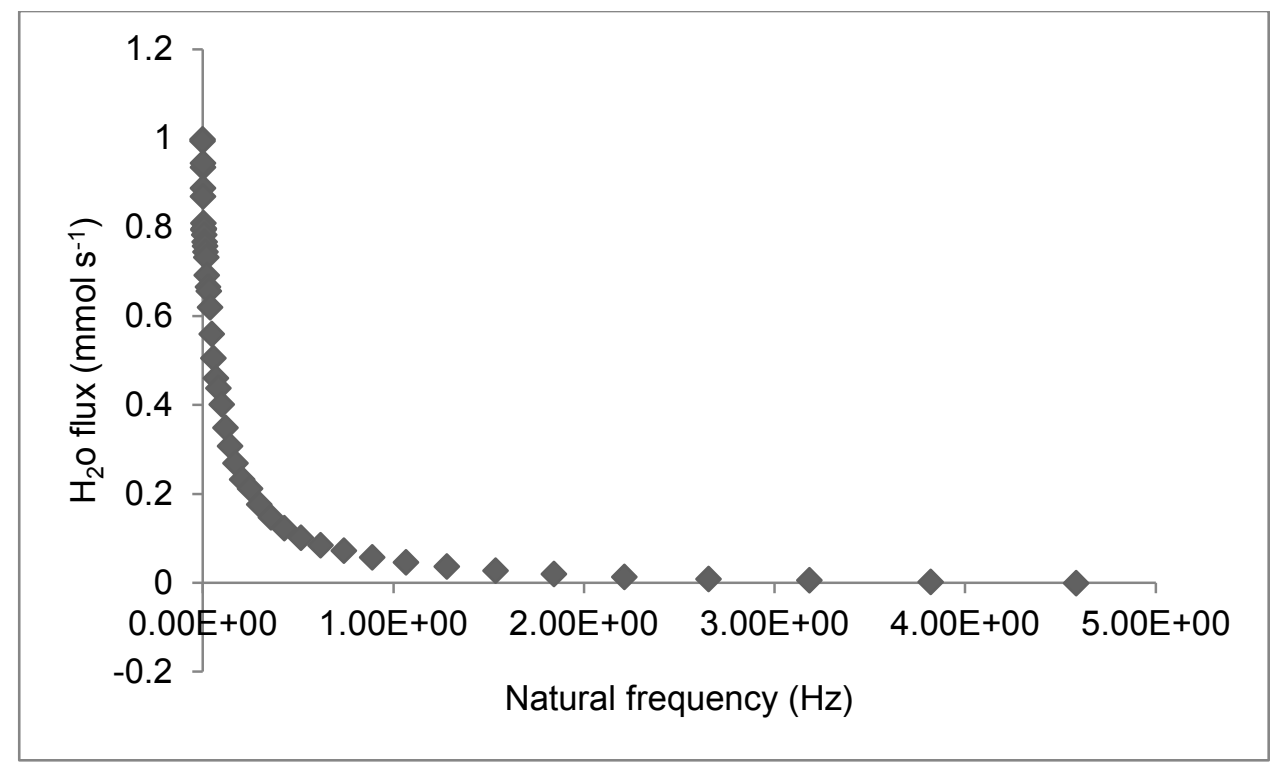

Figure 2. Cumulative co-spectra constructed over the 30 minute averaging time

\subsection{Flux foot print analysis}

The source area varied greatly with stable times having greater foot print compared to the unstable times. On average, the source area ranged from about $78.4 \mathrm{~m}$ in November to 194 in May and the average fetch was about $132 \mathrm{~m}$ during the measurement time. This means that the average maximum fetch area ranged from $47 \%$ to $118 \%$ of the theoretical fetch based on the measurement height of $1.65 \mathrm{~m}$ above the canopy. During the months of November and February and January, the source area was shorter compared to the months of October, December, March, April and May. Figure 3a shows the variability in source area overtime (numbers 1-10 represent months of October 2015 to July 2016). The along-wind distance providing the highest (peak) contribution to the turbulent fluxes was about $21 \mathrm{~m}$ from the tower. As expected the along-wind distance contribution to turbulent fluxes increased with distance from the tower (Fig. 3a) with $90 \%$ of the fluxes coming from the furthest points from within the fetch (78-194 m). Between 28 and $37 \mathrm{~m}$ along-wind distance from the tower contributed about $50 \%$ to the total flux. Between 41 and $65 \mathrm{~m}$ away from the tower contributed about $70 \%$ to the flux and less than $22 \mathrm{~m}$ contributed about 10 and $30 \%$ of turbulent fluxes, respectively. The prevailing wind (43\%) came from between the SW and SE sectors and wind speed from this sector was between 1.5 and $2.1 \mathrm{~ms}^{-1}$. Northerly winds were also strong occurring about $25 \%$ of the time within the NWN and NE sectors with wind speed ranging from $0.05-3.1 \mathrm{~ms}^{-1}$ (Fig 3b)

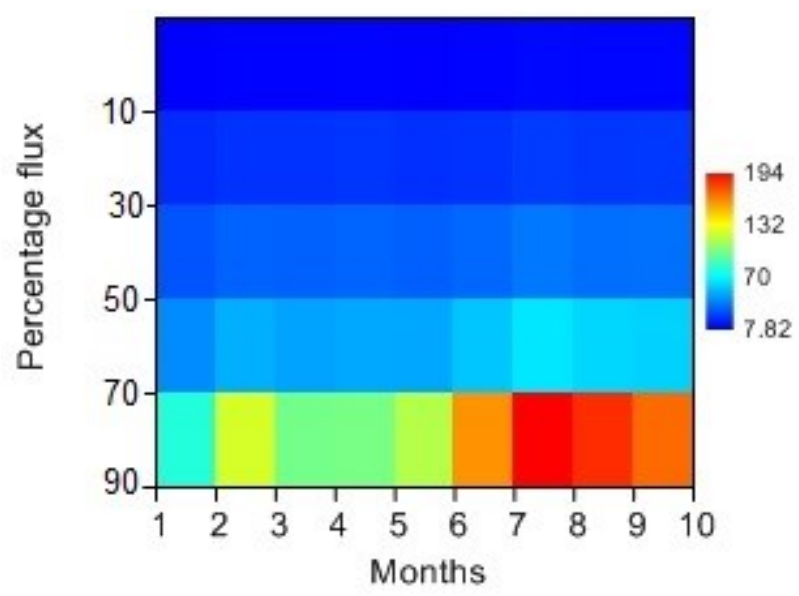

Figure3a. A surface diagram showing the flux source area and the along-wind distance percentage contribution to the total flux at eZulu station: numbers 1-10 represents months of October 2015 to July 2016. 


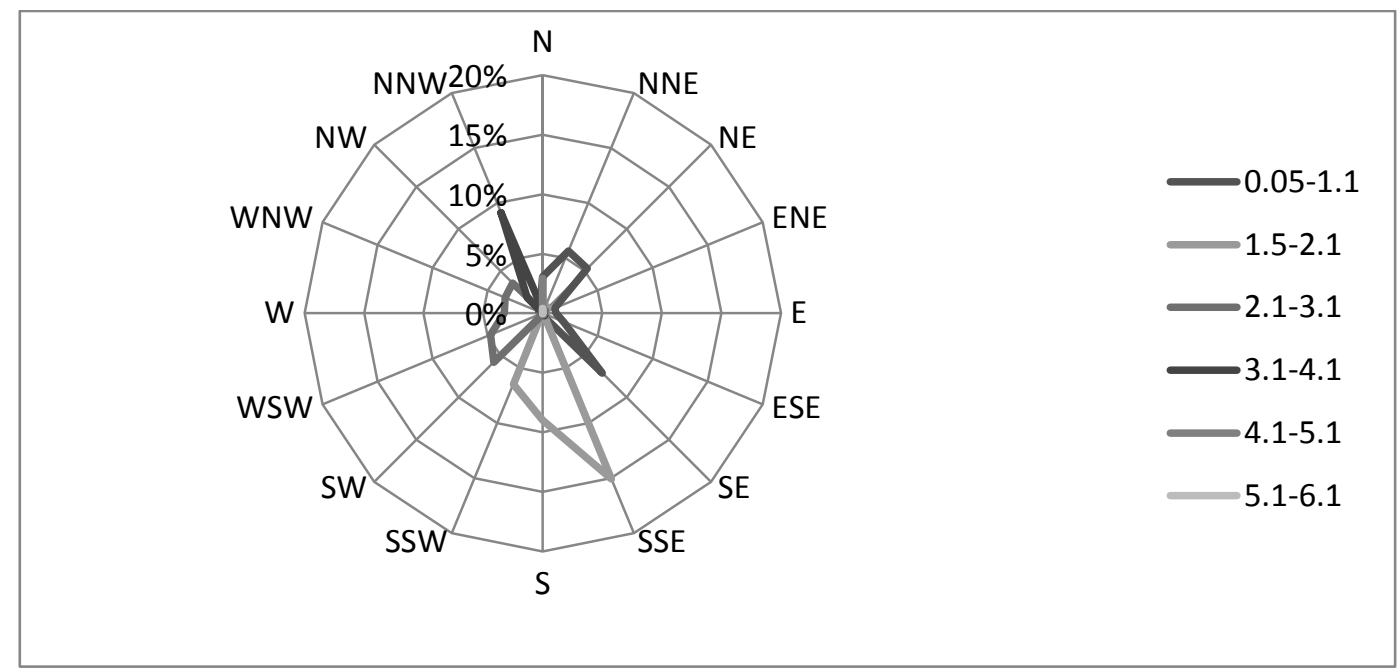

Figure $3 b$. A windrose of the direction and wind speed during the experiment at eZulu Flux Station.

\subsection{Energy fluxes and energy balance closure}

The pattern of energy fluxes over the measurement period is shown in Figure 4. Highest energy fluxes were recorded in February with Rn at 193.3 W.m ${ }^{-2}$ in February (Day of Year, DoY 53) while the maximum mean H (96.7) was recorded around DoY 63 of 2016 and highest $L E \quad\left(74 \mathrm{~W} . \mathrm{m}^{-2}\right)$ was recorded in DoY 69. The measured energy fluxes decreased progressively to about $15.6,4.1 \mathrm{Wm}^{-2}$ for $\mathrm{Rn}$ and $\mathrm{H}$ respectively by DoY 160 (Fig. 5). Starting from DoY 130 to DoY $160, R n$ and $H$ were almost equal in magnitude. During the study period, the average daily $\mathrm{Rn}, \mathrm{LE}, \mathrm{H}$ and $\mathrm{G}$ were $60.2 \pm 46,21.4 \pm 17,35.2 \pm 22$ and $-0.4 \pm 6.7 \mathrm{Wm}^{-2}$ respectively. The $\mathrm{G}$ was consistently lower than the three other fluxes during the experiment and it became asymptotically zero by DoY of 126 (2016) and began to fluctuate around zero after DoY 152. The LE was also consistently lower than Rn and H although few spikes were noted (for example on DoY 56 , 66-69, 109, 168 and 180). The coefficients of variation for Rn, H and LE were 76, 62, and 80\% respectively.

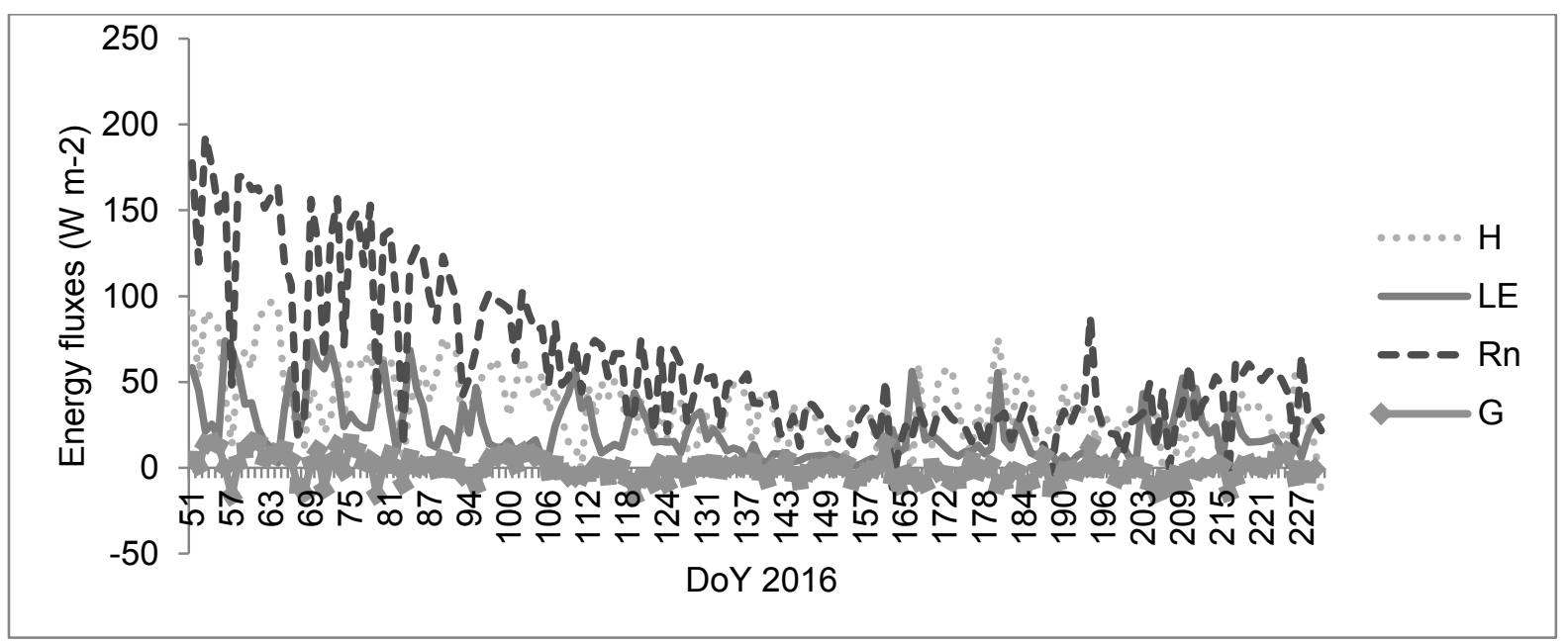

Figure 4. Daily variation in sensible heat $(H)$, net radiation $(\mathrm{Rn})$, latent heat (LE) and ground heat flux $(\mathrm{G})$ during the measurement periodwhen the net radiometer was available at eZulu station.

The daily pattern of energy fluxes were examined on typical days in February, March and April. We selected DoY February 20 (LE higher than G but less than H), 9 March (LE higher than H and G) and April 20 when LE was the lowest 
during day time. In general, the energy fluxes followed a similar pattern regardless of the month or flux partitioning. The fluxes increased during the morning and peaked at around $12 \mathrm{~h} 30$ local time (Fig 5a-c).

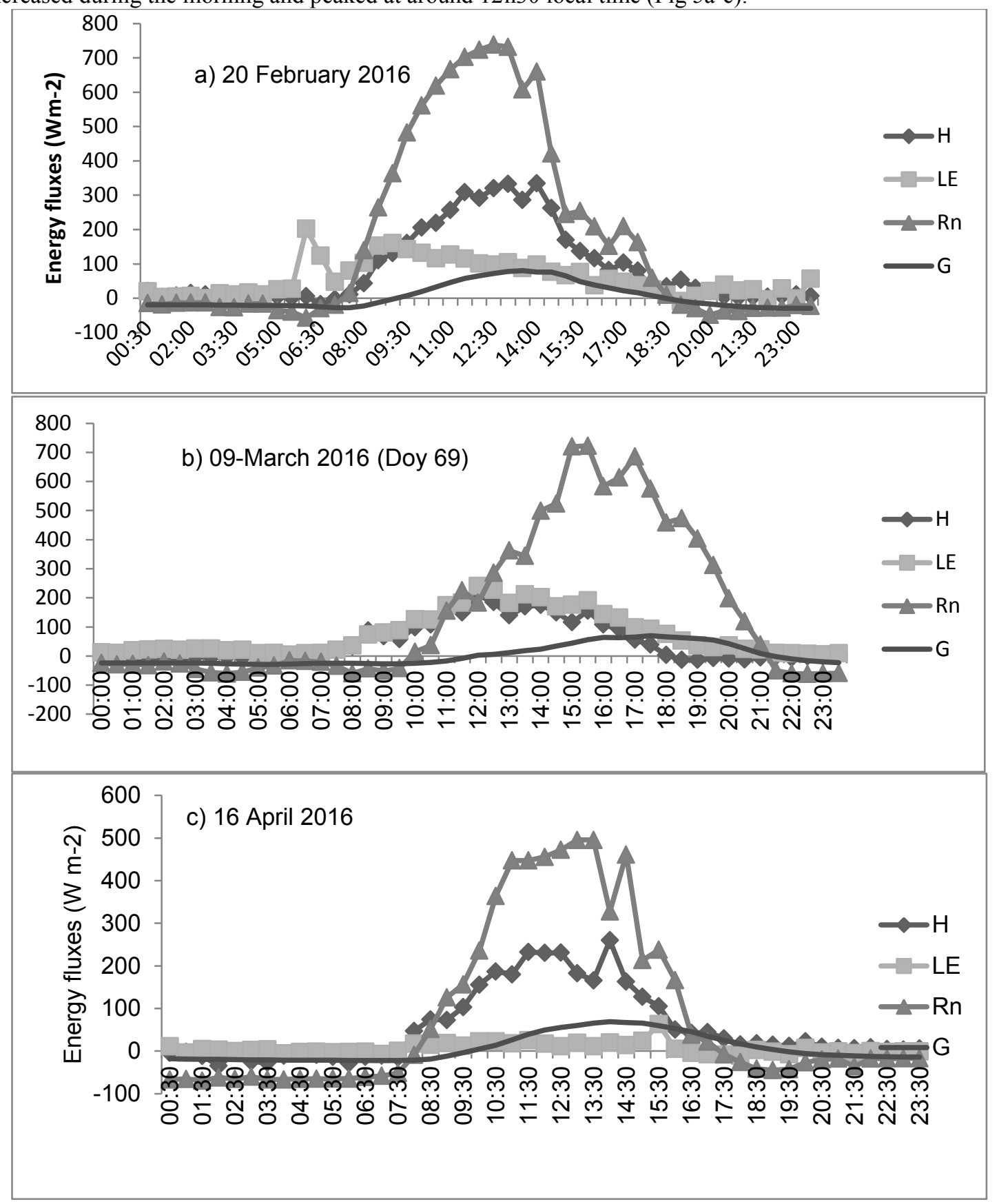

Figure 5(a-c). Daily patterns of energy balance components on three typical days in February, March and April, 2016.

The relationship between available energy and the sum of $H$ and LE was significant $\left(p<0.001, R^{2}=0.81\right)$, and the slope and intercept were 0.7 and 14.2 respectively (Fig. 6). The energy balance closure ratio (EBR) was 0.92 and available energy $(R n-G)$ was higher than $H+L E$ by about $18 \%$. 


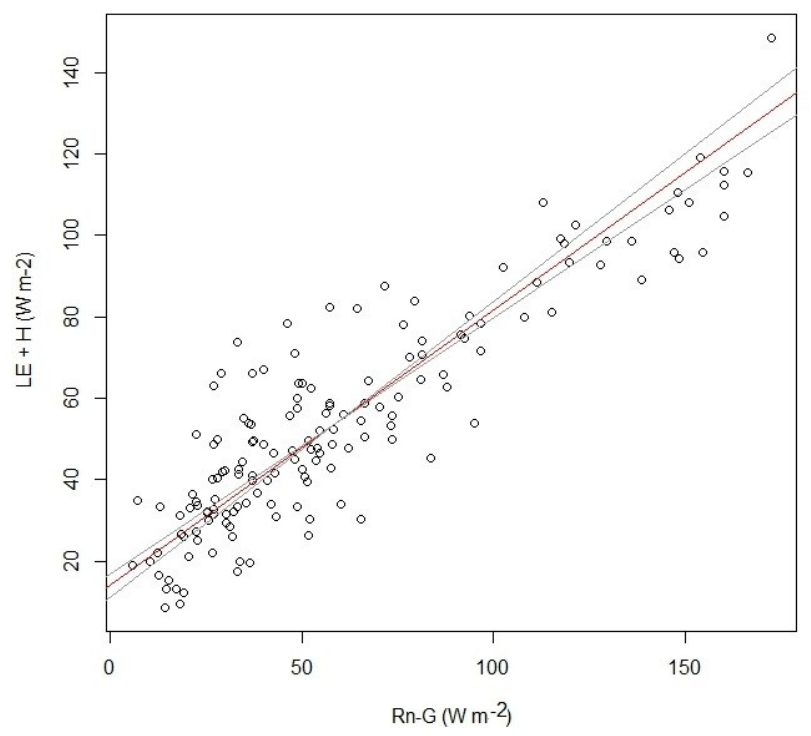

Figure 6. Energy balance closure at eZulu Game Reserve Flux tower.

\subsection{Meteorological conditions}

Mean \pm standard deviation (SD) meteorological conditions during the experiment are shown in Table 1.

Table 1. Mean daily meteorological conditions during the measurement period at eZulu Game reserve station.

\begin{tabular}{|l|l|}
\hline Meteorological parameter & Mean \pm SD \\
\hline Air temperature $\left({ }^{0} \mathrm{C}\right)$ & $19.8 .6 \pm 4.9$ \\
\hline Soil temperature $\left({ }^{0} \mathrm{C}\right)$ & $24.3 \pm 7.4$ \\
\hline Relative humidity $(\%)$ & $60.14 \pm 14$ \\
\hline Vapour pressure deficit $(\mathrm{Pa})$ & $1250.8 \pm 574$ \\
\hline Solar radiation $\left.\mathrm{MJ} \mathrm{m}^{-2}\right)$ & $18.1 \pm 7.5$ \\
\hline Wind speed $\left(\mathrm{ms}^{-1}\right)$ & $1.77 \pm 0.76$ \\
\hline Rainfall $(\mathrm{mm})$ & $0.851 \pm 2.8$ \\
\hline
\end{tabular}

The daily minimum and maximum temperatures were $8.32^{\circ} \mathrm{C}$ (DoY 184 of 2016) and $39.7^{\circ} \mathrm{C}$ (DoY 334 of 2015 ) respectively. The coefficient of variation was $24.73 \%$. Daily soil temperature ranged from $14.4-39.7^{\circ} \mathrm{C}$ with a coefficient of variation of $30 \%$. Soil temperature was consistently higher than air temperature up to around DoY 111 when the two became more or less equal (Fig. 7a). The lowest relative humidity (RH) recorded was14.1 (DoY 2253) and maximum at $92.8 \%$ (DoY 680, 2016) while the coefficient of variation was 23\%. The lowest solar radiation was at 3.24 (DoY 167) and highest at $31.30 \mathrm{MJ} \mathrm{m}^{-2}$ (DoY 358, 2015). Average solar radiation progressively declined from DoY of 356, 2015) to a minimum by DoY 167 (2016) with a coefficient of variation of 38.3\% (Fig. 7d). Mean daily precipitation during the period of measurement was $0.94 \pm 3.0 \mathrm{~mm}$. Maximum daily rainfall of $20 \mathrm{~mm}$ was recorded on DoY 73 (2016). Rainy days were clustered from the beginning of the experiment (DoY 296-333) followed by a dry period from DoY 334, 2015 to DoY 14 2016. Another cluster of relatively wetter days was between DoY 15 and DoY 136 (2016), followed by another dry spell from DoY 136 to 160 with a wetter spell thereafter. Rainfall had the highest coefficient of variation of 325\%. Mean daily Vapour Pressure Deficit (VPD) ranged from 162.61 Pa (DoY 207 2016) to 3334.9 Pa (DoY 32) with a coefficient of variation of $45.9 \%$. Finally, wind speed ranged from 0.37 to $4.69 \mathrm{~m} \mathrm{~s}^{-1}$. 


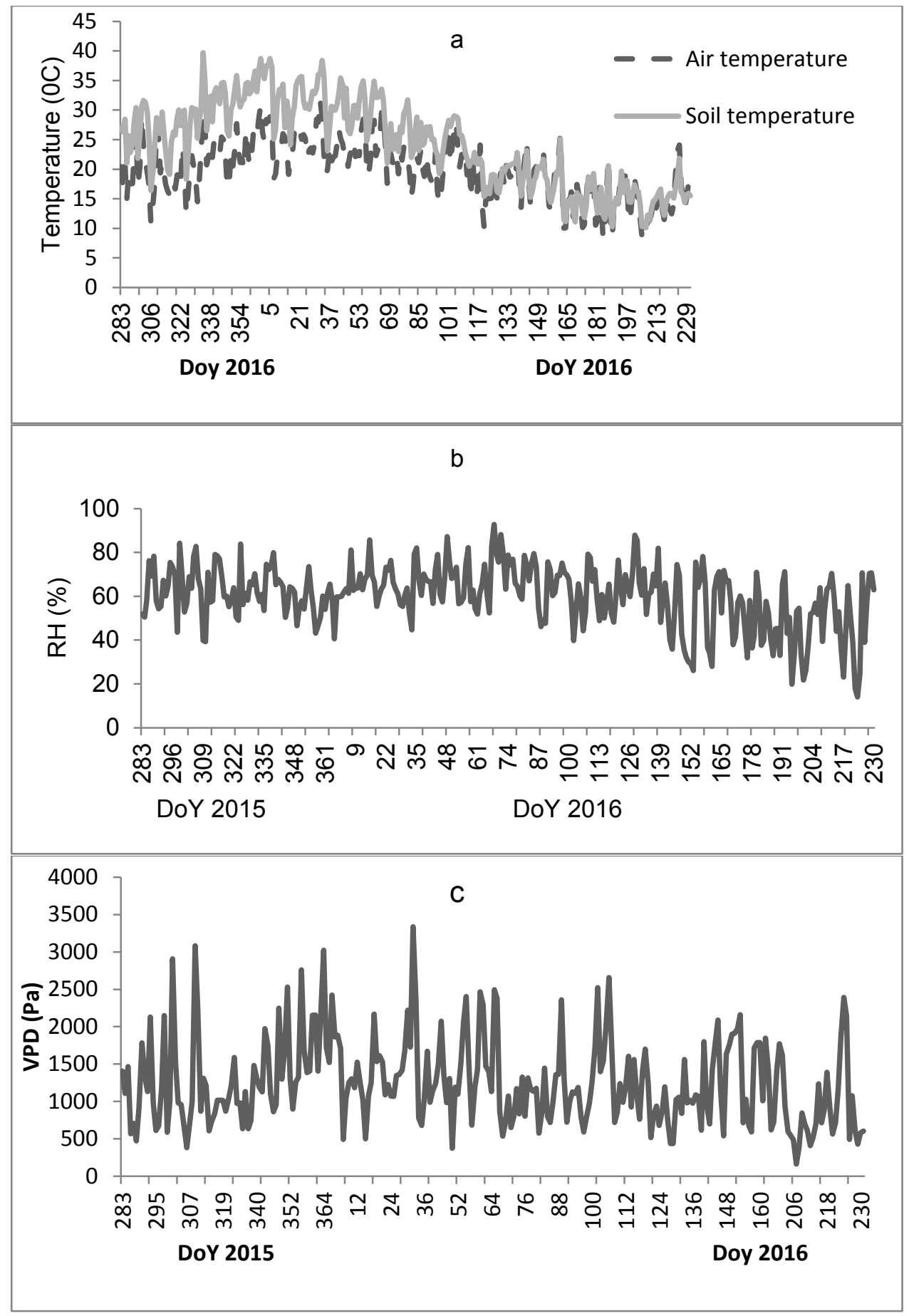




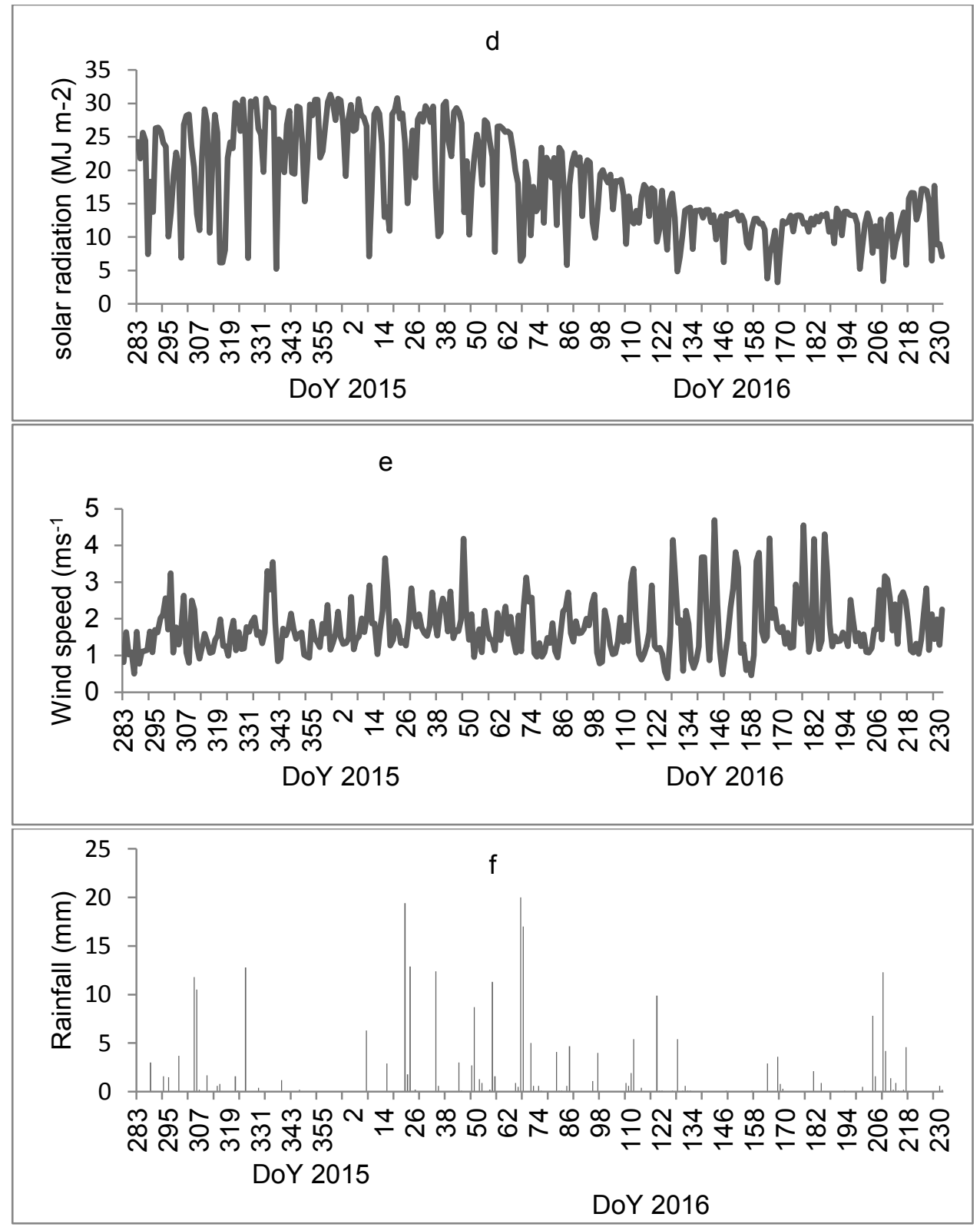

Figure 7. Daily variation in a) air temperature and soil temperature b) Relative humidity, c) Vapour Pressure deficit (VPD), d) solar radiation, e) wind speed and f) rainfall at eZulu during the study period.

\subsection{Variation in ET at the eZulu station}

Mean daily ET was $1.27 \mathrm{~mm}$ with a maximum daily ET of about $5 \mathrm{~mm}$ recorded on DoY 47 (2016) while the minimum occurred around DoY 201 in winter (Figure 8). Potential ET (ET0) was higher than actual ET for most of the measurement time, indicating that the environment was water limited (Fig. 8). 


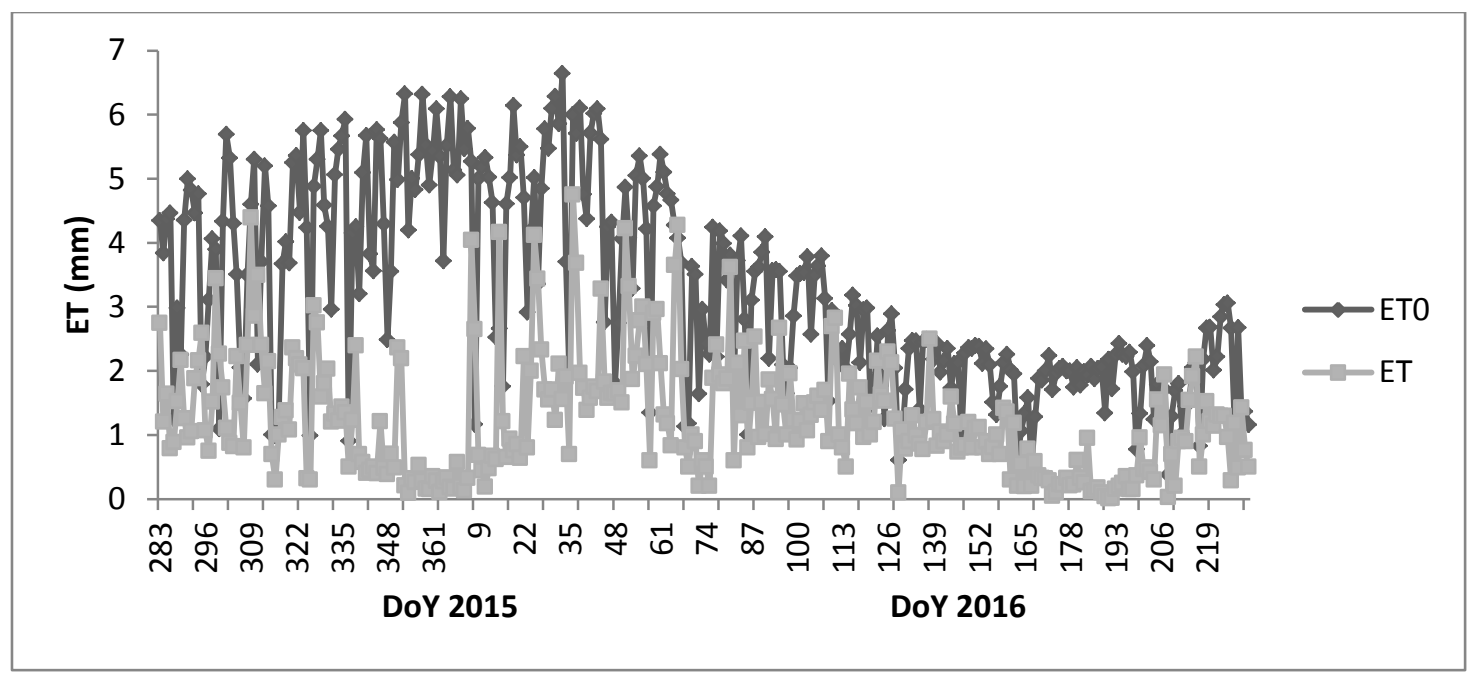

Figure 8. Daily variation in potential reference evapotranspiration (ET0) and actual ET at eZulu during 2015-2016.

As expected, the daily pattern of ET showed that water loss occurs mainly during the day light hours (Fig 9a-c). Typical days were chosen to show the pattern of ET throughout the day during dry and wet seasons (Fig 9). During the wet period daily ET peaked between $12 \mathrm{~h} 00$ hours and 14h00 hours coinciding with periods of highest VPD of 2556.9 Pa (March 13, 2016). However, during the drier period, peak ET occurred in the morning before VPD reached its maximum (Fig 9b-d). For example, on 11 May, peak ET was reached around $11 \mathrm{~h} 30$ yet maximum VPD was recorded at 1500 hours. A similar pattern was observed on December 7, 20 and 26 (2015) with ET peaking between 08h30 and 09h30 yet VPD peaked later in the day. For example, on 20 December maximum ET of the day occurred at 08h30, yet VPD was low at this time at $1193 \mathrm{~Pa}$, peaking at $1723.8 \mathrm{~Pa}$ at $11 \mathrm{~h} 30$ hours. On such days positive fluxes would stop as early as around 09h30 hours despite high and favourable atmospheric demand for ET to take place.

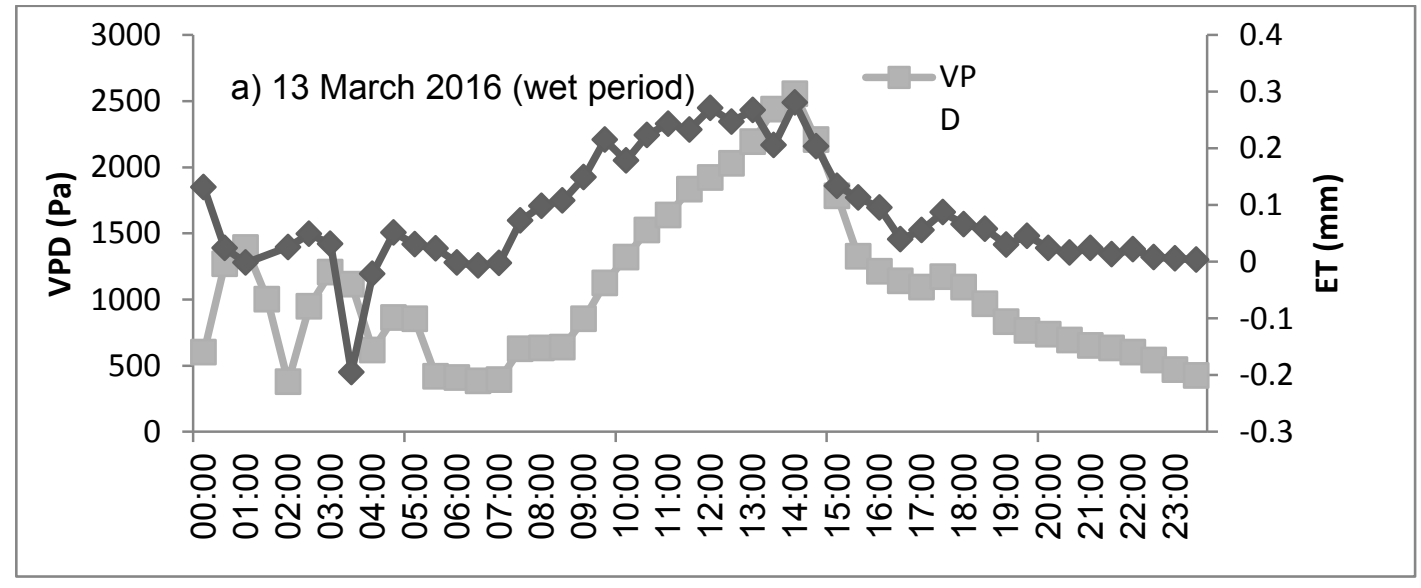




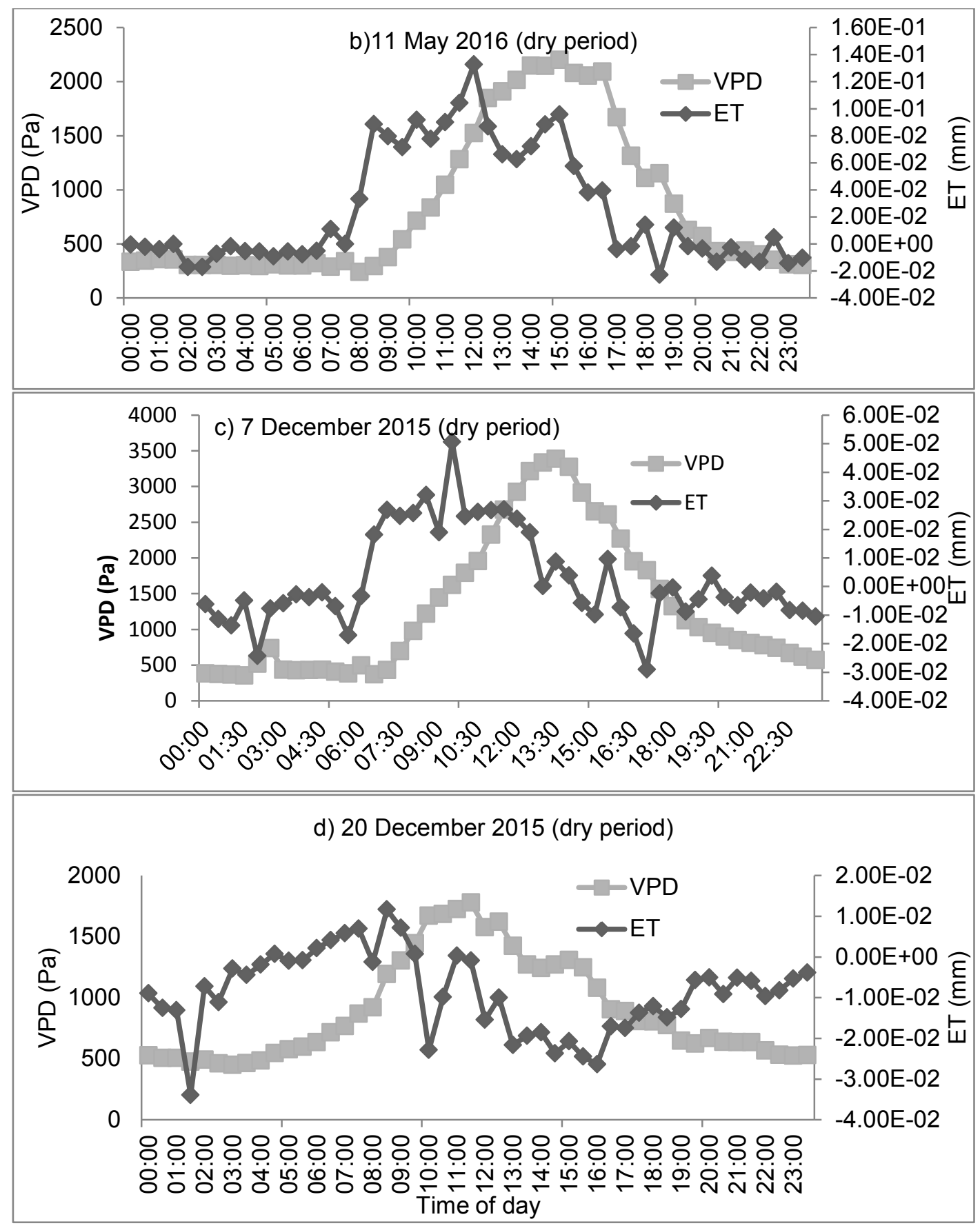

Figure 9. Pattern of ET and VPD on four different days at eZulu during: a) wet and b-d) dry period

\subsection{Relationship between ET and environmental factors}

The trends of ET generally followed changes in rainfall and soil moisture. However, minimum ET was observed in DoY 191 (2016) while minimum SWC of about 0.063 was observed on DoY 7 (2016). Maximum SWC (0.17 occurred on DoY 68 (2016) with a corresponding ET of about $4.5 \mathrm{~mm}$. Maximum ET of about $5 \mathrm{~mm}$ occurred on DoY 47 (2016) when the corresponding SWC was about 0.12 and the period between DoY 136 and 160 (2016) was characterised by very low rainfall (Figure 10b). In general high ET rates occurred even during periods of high moisture deficit. For exam- 
ple, high ET values of up to $2.4 \mathrm{~mm}$ were recorded when SWC was relatively lower (0.063-0.07) during the period between DoY 336 and DoY 351 (2015). The ET trend followed that of LAI. Figure 10c shows the accumulated ET over 8 day periods to match the MOD $15 \mathrm{~A}$ LAI product ${ }^{34,35}$ availability.

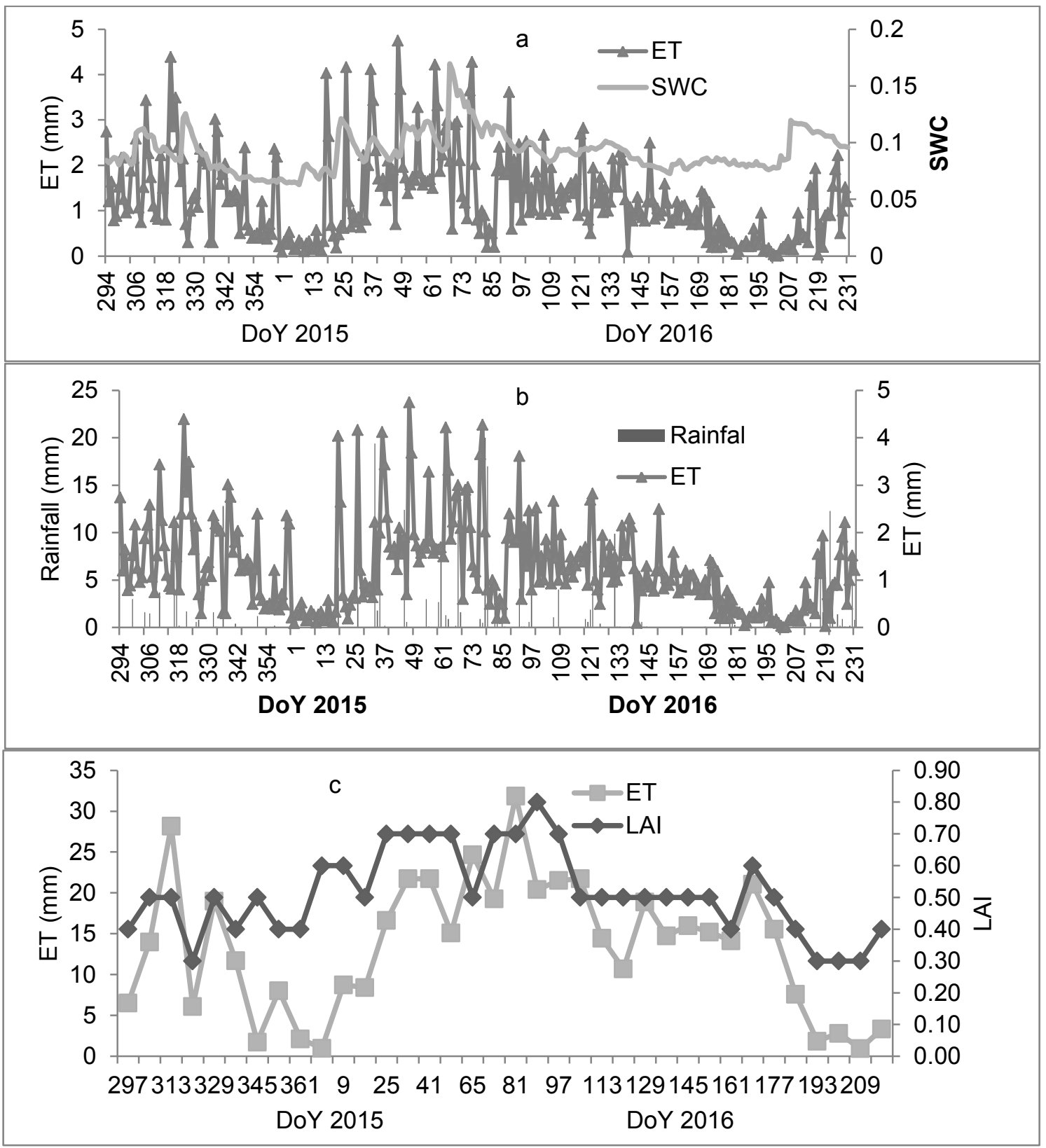

Figure 10. Trends in ET and environmental controls: a) volumetric soil water content (SWC), b) rainfall and c) leaf area index (LAI) at eZulu Game Reserve Station

Mean LAI was $0.52 \pm 0.13 \mathrm{SD}$ and ranged from 0.3 to 0.8 with a coefficient of variation was $25 \%$. Average SWC was $0.091 \pm 0.017$ and soil was driest $(\mathrm{SWC}=0.063)$ around DoY $7(2016)$ and wettest $(\mathrm{SWC}=0.17, \mathrm{DoY} 68,2016)$ and the coefficient of variation was $19.4 \%$. Soil moisture accounted for about $32 \%(p<0.001)$ variation in ET over time with a slope of 72 (T Fig. 11a). The LAI accounted for about $41 \%(\mathrm{p}<0.05)$ variation in daily ET and the slope of the regression was 61.2. Standard Major Axis regression detected a weak and slightly negative correlation between VPD and ET 
$(\mathrm{p}<0.05)$ at the eZulu site. Both available energy and Rn had weak positive correlation with ET although the former had a slightly higher $\mathrm{R}^{2}$ (Fig. 11d-e).
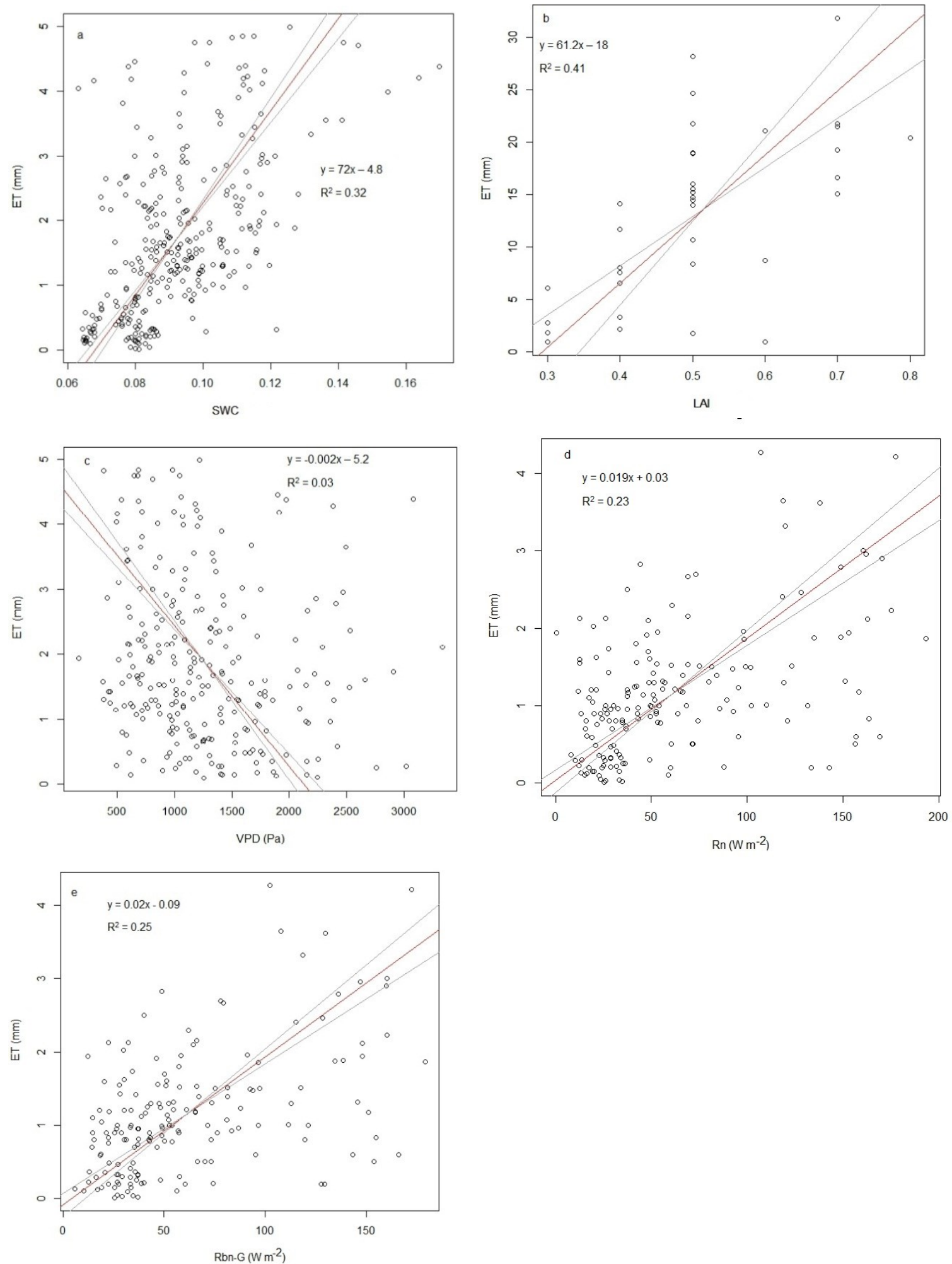

Figure 11. Relationship of ET with the main environmental controls of evapotranspiration at the eZulu site: a) volumetric soil water content (SWC), b) leaf area index (LAI), c) Vapour Pressure Deficit (VPD), d) net ration (Rn) and e) available energy (Rn-G). 


\section{DISCUSSION}

\subsection{Data quality and uncertainty in gap filling}

The study sought to understand the pattern of ET over the AT vegetation of South Africa. Good data quality is crucial in calculating long-term turbulent fluxes. Therefore, we subjected our data to quality scrutiny which included flux footprint analysis, site energy balance and co-spectral analysis. The eddy covariance theory is based on a number of assumptions which are rarely met in the real world ${ }^{22}$. Consequently, a number of errors are bound to occur in the application of the EC theory. For example, measurement errors due to factors such as instrument or system failure are inherent in turbulent fluxes measurements. Therefore, it becomes prudent to screen data to achieve the highest quality and reduce uncertainties in computed fluxes. For our station, about $77 \%$ of the flux data passed quality flags as described by ${ }^{29}$. Our data availability was within the observed ranges from elsewhere. For example, ${ }^{30}$ reported data coverage of about $65 \%$ while ${ }^{20}$ recorded values of between 57 and $84 \%$. Therefore, this high percentage of data availability contributed greatly to reducing uncertainties associated in the computed fluxes. The adoption of a well-established gap filling method for missing and rejected data also helped to reduce the uncertainties of calculated fluxes.

We checked if all low frequency parts are included in the flux measured by the EC using the ogive test. Our data passed the ogive test within the 30 minute averaging window and subsequently, fluxes were calculated using this averaging window. This means that the whole turbulent range was captured within the 30 minute averaging time and the contribution to the total flux by longer wavelengths was insignificant in this window. Hence, the fluxes calculated within the 30 minute window are a true representation of turbulent exchanges. An analysis of energy balance closure is also a crucial yardstick to assess the accuracy of calculated fluxes. The surface energy balance is closed when the energy flux into a system is equal to the energy flux leaving the system, plus any energy storage change in the system. Using the shortened energy balance equation, our results show that the available energy over-predicted the sum of $\mathrm{H}$ and LE. It is widely accepted that energy balance cannot be closed by experimental data ${ }^{36-38}$ since measurement errors and errors in the EC method cannot adequately explain energy imbalance at the surface ${ }^{37,39-40}$. Lack of energy balance closure is attributed to variations in the landscape architecture which influences the turbulent exchange and may cause advection of energy from one area to the other ${ }^{39}$ and the problem has been found in flux towers elsewhere. The EC system at eZulu Game Reserve also recorded some spikes in LE that were greater than Rn and this suggests that advection occurred during some of the days. We found an energy balance closure ratio of about 0.92 and $\mathrm{R}^{2}$ of 0.81 . This result is consistent with the $70-90 \%$ closure observed across the globe ${ }^{36,38,40-41}$. In South Africa over the savannah biome ${ }^{42}$ reported an average closure ratio of 0.93 (ranging from 0.44 to 3.76). In addition, average daily LE was the smallest flux compared to $\mathrm{Rn}$ and $\mathrm{H}$ throughout the measurement period. Most of the Rn was consumed by $\mathrm{H}$ and this means that ET in the area is essentially water limited since abundant energy was available to drive the turbulent transfers of energy.

The source area was variable over time and this was linked to the overall stability of the atmosphere. During the relatively unstable months of November, January and February the mean source area was relatively smaller compared to more stable months of October, December, March, April and May as the stability parameters for respective months revealed. The values of the stability parameter may range from negative to positive infinity and the extreme values correspond to the limits of the heat flux approaching zero from the positive (unstable) and negative (stable) side, respectively. When the stability parameter is $>0$, stable conditions prevail and unstable conditions prevail when the stability parameter is $<0$

${ }^{43}$. Therefore the size of the source area was strongly coupled with the atmospheric turbulence phenomena as determined by the stability parameter. The prevailing wind (south easterly and south westerly) ensured that most fluxes recorded were reflective of turbulent fluxes of the target vegetation. The maximum fetch of the station overshot the theoretical limit during absolute stable times. This shows that the theoretical 1:100 $\mathrm{m}$ for a fetch reported in literature ${ }^{39}$ can be violated.

\subsection{Linking ET to environmental controls}


The results showed that the average meteorological conditions were conducive for ET to take place. For example, the air temperature, RH, VPD and solar radiation were high enough to encourage ET and were not highly variable as revealed by their coefficients of variation (Table 1).The SWC was relatively stable compared to rainfall. Although rainfall and soil moisture are closely coupled, the stability in soil moisture is reflective of the ability of soil to store water for longer periods. This is crucial since it avails water to drive ET during the dry spells. The stability of SWC may also suggest intricate coupling between the upper soil surface zone and ground water since capillary action could be vital in stabilizing soil moisture. It has also been established that the storage and movement of water in the soil profile is not wellknown and is the least understood aspect of the hydrological cycle owing to uncertainties associated with the extent to which groundwater situated in aquifers or water derived from unsaturated flow in soils contribute to baseflows and even stormflows ${ }^{44}$. In addition, the recorded SWC may not be reflective of the amount of water available for ET since the water reflectometers were buried just $25 \mathrm{~mm}$ in the soil, yet more moisture could be available to the deeper roots. Therefore, locating such sensor at different depths could be crucial to capture dynamics in plant available moisture.

\subsection{Attribution of water flux}

Surprisingly, high ET rates were recorded during a dry spell and when SWC was low (Fig. 10a and b). This can be explained by the nature of vegetation where the measurements were collected. It is well established that Crassulacean Acid Metabolism (CAM) plants have high water storage capabilities within their tissues and have relatively low stomatal densities and lower conductance to water vapour ${ }^{14,45}$. CAM plants are also able to effectively use the small amount of precipitation received in such dry areas. These characteristics enable such succulent vegetation to make maximum benefit of water absorbed by their root system in improving tissue water relations. This stored water is crucial in sustaining physiological and metabolic functions between infrequent precipitation events ${ }^{15}$. In addition, CAM plants are able to isolate their roots from the soil through root xylem cavitation or embolism and shrinkage of root cortex which prevents reverse flux of water from the tissues into the soil at large soil water deficits. In addition, it is well established that CAM plants can survive loss of $80-90 \%$ of their water content and still continue to thrive, as may occur in exceptional periods of several years without rainfall (Borland et al. 2009). Therefore we speculate that the ET observed at eZulu may also be linked to long-term past rainfall events and the ability of succulents to store water in their aboveground tissues. Therefore, this convergent evolution of succulent plants makes accounting for ET and for the source of water for these plants quite difficult to attribute. At the same time the geology of the study area comprises of sandstone and shale and hence there is a distinct possibility that these plants accessed water locked in these geological formations. Therefore, further studies are required to ascertain the source of water that drives ET in this semi-arid AT biome.

An analysis of the diurnal pattern of ET was quite revealing in terms of biophysical controls to water loss. Generally, it is envisaged that the diurnal pattern of ET should peak around mid-day when VPD is highest. However, our results showed a variant from the expected. During conditions of moisture deficit in the landscape, ET peaked early between $08 \mathrm{~h} 30$ and 09h30 local time yet maximum VPD occurred later in the day. This suggests strong biological control to ET in the AT biome as the plants could be closing their stomata earlier in the day in order to optimise water use. This demonstrates the ability of thicket vegetation to optimise water use under conditions of moisture deficit and is consistent with the widely held view of drought avoidance associated with CAM plants ${ }^{14,45,15}$. This is also consistent with the convergence theory $^{47,48}$ that plants have evolved to optimise resource use. Our results also suggest that most ET in the AT takes place during daylight regardless of environmental constraints to ET. Therefore, results from this paper suggest that the AT may not be completely closing their stomata during the day but that the plants are opportunistic in their quest to exchange water vapour for carbon. This is not consistent with the generally held view that CAM plants completely close their stomata during the day ${ }^{14,46,47}$.

ET is a complex biophysical process modulated by abiotic and biotic factors. The main abiotic factors investigated in this paper include temperature, solar radiation, net radiation, $\mathrm{RH}$, soil water content, wind speed and rainfall. Our results indicated that SWC was the most influential abiotic factor at the study site, accounting for much of the variation in ET. This was not surprising since moisture is a prerequisite for ET to take place. We found no meaningful relationship between VPD and ET at both 30 minute intervals and daily averages. The daily data showed an inverse relationship between ET and VPD, suggesting that atmospheric demand was high and could not be met by moisture content of the soil. In addition, both available energy and $\mathrm{Rn}$ radiation had weak relationship with ET. These dynamics help to confirm that ET in the AT is water limited. With respect to biotic factors we analysed the LAI. The ET pattern followed that of LAI which also followed the rainfall trend. It should be noted that transpiration is likely to be dominant over surface evapora- 
tion in this dry environment. The LAI accounted for about $41 \%$ variation in ET and the relationship was significant (p $<$ 0.001). This result is consistent with that of ${ }^{18}$ who found that LAI explained between $21-47 \%$ of the variation of ET in the Mongolian steppe. We have also noted that maximum ET recorded between $08 \mathrm{~h} 30$ and $09 \mathrm{~h} 30$ hours at the lower end of the VPD gradient is suggestive of a strong biotic control of ET related to the opening and closure of the stomata. Therefore, biotic factors influenced ET through LAI and the convergent evolution of the AT related to its water storage capacity and the ability of the dominant CAM plants to control stomatal conductance. These eco-physiological characteristics are likely to promote higher water use efficiency in our study site as reported elsewhere (for example, ${ }^{15,46}$. These results are in sharp contrast with findings by ${ }^{19}$ who noted no meaningful relationship between ET and biotic factors represented by LAI in grasslands of Inner Mongolia. The contrasting results can be explained by vegetation characteristics.

\section{CONCLUSION}

The study sought to understand ET trends in the AT of South Africa. Our data was within the acceptable data availability thresholds and therefore adaptable for long-term computation of ET. Rigorous quality control helped to reduce uncertainties in the calculated fluxes. ET in the study area was essentially water limited as much of the Rn was consumed by $\mathrm{H}$ and also the difference between potential ET and actual ET was high. In terms of environmental controls to ET, soil moisture and plant development represented by LAI were the most influential factors in controlling ET. The ET trend highlighted strong complex biophysical control of the ET process. Trends in ET suggest that stomatal conductance is likely to be one of the main biotic controls of ET in the study area. The subtropical thicket vegetation returned more ET than rainfall received due to the convergent evolution of the plants to avoid water deficits through high water storage capacities and the possibility of tapping ground water trapped in aquifers as well as stomatal conductance. However, further research will be prudent to establish the sources of water and quantify the relative contribution to total ET observed in such environments.

\section{ACKNOWLEGDEMENTS}

The research was supported by the National Research Foundation of South Africa (National Equipment Programme) and the Water Research Commission (project K5/2400/4)

\section{REFERENCES}

[1] Allen, R. G., Pereira, L. S., Raes, D.., Smith, M., [FAO Irrigation and Drainage Paper N0. 56: Crop Evapotranspiration (guidelines for computing crop water requirements], FAO, Rome (1998).

[2] Fisher, J. B., Whittaker, R. J., Malhi, Y., Taylor, P., "ET come home: potential evapotranspiration in geographical," Glob. Ecol. Biogeogr. 20, 1-18 (2011).

[3] Fisher, J. B., DeBiase, T. A., ., Qi, Y., Xu, M.., Goldstein, A. H., "Evapotranspiration models compared on a Sierra Nevada forest ecosystem," Environ. Model. Softw. 20(6), 783-796 (2005).

[4] Mu, Q., Zhao, M.., Running, S. W., "Improvements to a MODIS global terrestrial evapotranspiration algorithm," Remote Sens. Environ. 115(8), 1781-1800, Elsevier Inc. (2011).

[5] Hoff, H., Falkenmark, M., Gerten, D., Gordon, L., Karlberg, L.., Rockström, J., “Greening the global water system," J. Hydrol. 384(3-4), 177-186, Elsevier B.V. (2010).

[6] McMahon, T. a., Peel, M. C., Lowe, L., Srikanthan, R., McVicar, T. R., "Estimating actual, potential, reference crop and pan evaporation using standard meteorological data: a pragmatic synthesis," Hydrol. Earth Syst. Sci. 17(4), 1331-1363 (2013).

[7] Liou, Y.-A.., Kar, S., "Evapotranspiration Estimation with Remote Sensing and Various Surface Energy Balance Algorithms - A Review," Energies 7(5), 2821-2849 (2014).

[8] Fisher, J. B., Baldocchi, D. D., Misson, L., Dawson, T. E.., Goldstein, A. H., "What the towers don't see at night: nocturnal sap flow in trees and shrubs at two AmeriFlux sites in California.," Tree Physiol. 27(4), 597-610 (2007).

[9] Ruhoff, A. L., Roux, E., Paz, a. R., Aragao, L. E. O. C., Mu, Q., Malhi, Y., Collischonn, W., Rocha, H. R., Running, S. W., et al., "Assessment of the MODIS global evapotranspiration algorithm using eddy covariance measurements and hydrological modelling in the Rio Grande basin,” Hydrol. Sci. J. 58(October), 1658-1676 (2013). 
[10] Ma, N., Zhang, Y., Guo, Y., Gao, H., Zhang, H.., Wang, Y., "Environmental and biophysical controls on the evapotranspiration over the highest alpine steppe," J. Hydrol. 529, 980-992, Elsevier B.V. (2015).

[11] Franks, P. J., Adams, M. A., Amthor, J. S., Barbour, M. M., Berry, J. A., Ellsworth, D. S., Farquhar, G. D., Ghannoum, O., Lloyd, J., et al., "Sensitivity of plants to changing atmospheric CO 2 concentration : from the geological past to the next century," New Phytol. 197, 1077-1094 (2013).

[12] Hoare, D.B., Mucina, L., Rutherford, M.C., Vlok, J.H.J., Euston-Brown, D.I.W., Palmer, A.P., Powreie, L.W., Lechmere-Oerttel, R.G., Proches, S.M., Dold, A.P. and Wart, R.A., “Albany Thicket Biome," In Mucina L, Rutherford MC, (eds.), [The vegetation of South Africa, Lesotho and Swaziland]. Strelitzia 19, South African National Boidiversity Institute, Pretoria, 540-567(2006).

[13] Mills, A. J.., Cowling, R. M., "Rate of carbon sequestration at two thicket restoration sites in the Eastern Cape, South Africa," Restor. Ecol. 14(1), 38-49 (2006).

[14] Borland, A. M., Griffiths, H., Hartwell, J.., Smith, J. A. C., "Exploiting the potential of plants with crassulacean acid metabolism for bioenergy production on marginal lands," J. Exp. Bot. 60(10), 2879-2896 (2009).

[15] Owen, N. A., Choncubhair, Ó. N., Males, J., del Real Laborde, J. I., Rubio-Cortés, R., Griffiths, H.., Lanigan, G., "Eddy covariance captures four-phase crassulacean acid metabolism (CAM) gas exchange signature in Agave," Plant, Cell Environ. 39(2), 295-309 (2016).

[16] van Luijk, G., Cowling, R. M., Riksen, M. J. P. M.., Glenday, J., "Hydrological implications of desertification: Degradation of South African semi-arid subtropical thicket," J. Arid Environ. 91, 14-21, Elsevier Ltd (2013).

[17] Becker, C H., Coetsee, C., Cowling, R.M., P. A. J., "Soil factors influencing the distribution of spekboom ( portulacaria afra ) in sub- tropical thicket.," South africna J. Bot. 101, 107-111 (2015).

[18] Li, S. G., Asanuma, J., Kotani, A., Davaa, G., Oyunbaatar, D., "Evapotranspiration from a Mongolian steppe under grazing and its environmental constraints," J. Hydrol. 333(1), 133-143 (2007).

[19] Wang, L., Liu, H., Ketzer, B., Horn, R.., Bernhofer, C., "Effect of grazing intensity on evapotranspiration in the semiarid grasslands of Inner Mongolia , China," J. Arid Environ. 83, 15-24, Elsevier Ltd (2012).

[20] Liu, S. M., Xu, Z. W., Zhu, Z. L., Jia, Z. Z., Zhu, M. J., "Measurements of evapotranspiration from eddycovariance systems and large aperture scintillometers in the Hai River Basin, China," J. Hydrol. 487, 24-38 (2013).

[21] Baldocchi, D., "ESPM 228, Advanced Tropics in Biometeorological and Micrometeorology, Lecturer 3 Micromet Flux Measurment, Eddy Covariance, Part 1, Department of Environmental Science, Policy and Management," 1-22 (2012),10 April 2016, www.learningace.com/.../lecture-3-notes-espm-228-micromet-fluxmeasurements-edd..

[22] Burba, G., [Eddy Covariance Method for Scientific, Industrial, Agricultural, and Regulatory Applications: A Field Book on Measuring Ecosystem Gas Exchange and Areal Emission Rates] LI-COR Biosciences, Lincoln, Nebraska (2013).

[23] Campbell Scientific., [Open Path Eddy Covariance System Operator 's Manual] (2013).

[24] Schulze, R.E., [South African Atlas of Agrohydrology and Climatology], WRC Report TT82/96, Water Research Commission, Pretoria (1997).

[25] Campbell Scientific, C., [Integrated Open-Path Gas CO 2 /H 2 O Analyzer and 3D Sonic Anemometer, Instruction manual] (2015).

[26] Campbell Scientific., [Model HFP01 Soil Heat Flux Plate, Instruction Manual] (2002).

[27] Vickers, D., Mahrt, L., "Quality control and flux sampling problems for tower and aircraft data," J. Atmos. Ocean. Technol. 14(3), 512-526 (1997).

[28] Finkelstein, L.P., \& S. P. ., "Sampling error in eddy correlation flux measurements," Geophys. Res. 106(D4), 3503-3509 (2001).

[29] Mauder, M.., Foken, T., "Quality control of eddy covariance measurements (C: 0,1,2)," 29-31 (2004).

[30] Falge, E., Baldocchi, D., Olson, R., Anthoni, P., Aubinet, M., “Gap filling strategies for long term energy flux data sets," Agric. For. Meteorol.(107), 71-77 (2001).

[31] Kljun, N., Calanca, P., Rotach, M. W., Schmid, H. P., "A simple parameterisation for flux footprint predictions," Boundary-Layer Meteorol. 112(3), 503-523 (2004).

[32] Savage, M., Everson, C., Odhiambo, G., Mengistu, M.., Jarmain, C., [Theory and Practice of Evaporation Measurement, With Special Focus on Sls As an Operational Tool for the Estimation of Spatially averaged Evaporation] Water Research Commission, Pretoria (2004).

[33] Legendre, P., "Model II regression user's guide, R edition,” R Vignette 4, 1-14 (2013), 27 July 2016, https://cran.r-project.org/web/packages/lmodel2/vignettes/mod2user.pdf. 
[34] Myneni, R. B., Nemani, R. R.., Running, S. W., "Estimation of global leaf area index and absorbed par using radiative transfer models," IEEE Trans. Geosci. Remote Sens. 35(6), 1380-1393 (1997).

[35] Myneni, R., Knyazikhin, Y., Glassy, J., Votava, P.., Shabanov, N., “User' s Guide FPAR, LAI (ESDT: MOD15A2) 8-day Composite NASA MODIS Land Algorithm," Terra, 1-17 (2003).

[36] Wilson, K., Goldstein, A., Falge, E., Aubinet, M., Baldocchi, D., Berbigier, P., Bernhofer, C., Ceulemans, R., Dolman, H., et al., "Energy balance closure at FLUXNET sites," Agric. For. Meteorol. 113(1-4), 223-243 (2002).

[37] Foken, T., “The Energy Balance Closure Problem: an Overview,” Ecol. Appl. 18(6), 1351-1367 (2008).

[38] Kidston, J., Brümmer, C., Black, T. A., Morgenstern, K., Nesic, Z., McCaughey, J. H.., Barr, A. G., "Energy balance closure using eddy covariance above two different land surfaces and implications for CO2 flux measurements," Boundary-Layer Meteorol. 136(2), 193-218 (2010).

[39] Foken, T., Aubinet M. and Leuning, R., " The Eddy Covariance Method," In Aubinet, M., Vesala T. and Papale D. ( eds.) [Eddy covariance: A practical guide to measurement and data analysis], Springer Science+Business Media B.V. 2012, Springer Dordrecht, Heidelberg London, New York.pp 1-22 (2012).

[40] Kim, H. W., Hwang, K., Mu, Q., Lee, S. O.., Choi, M., "Validation of MODIS 16 Global Terrestrial Evapotranspiration Products in Various Climates and Land Cover Types in Asia," 229-238 (2012).

[40] Kim, S., Lee, Y.-H., Kim, K. R.., Park, Y.-S., “Analysis of surface energy balance closure over heterogeneous surfaces," Asia-Pacific J. Atmos. Sci. 50, 1-13 (2014).

[41] Barr, A. G., Morgenstern, K., Black, T. A., McCaughey, J. H.., Nesic, Z., "Surface energy balance closure by the eddy-covariance method above three boreal forest stands and implications for the measurement of the CO2 flux," Agric. For. Meteorol. 140(1-4), 322-337 (2006).

[42] Majozi, N. P., Mannaerts, C. M., Ramoelo, A., Mathieu, R., Nickless, A., Verhoef, W., “Analysing surface energy balance closure and partitioning over a semi-arid savanna FLUXNET site in Skukuza, Kruger National Park, South Africa," Hydrol. Earth Syst. Sci. Discuss.(March), 1-21 (2016).

[43] Schmid, H. P., "Source areas for scalars and scalar fluxes," Boundary-Layer Meteorol. 67(3), 293-318 (1994).

[44] Jewitt, G., "Integrating blue and green water flows for water resources management and planning," Phys. Chem. Earth, Parts A/B/C 31(15-16), 753-762 (2006).

[45] Carr, M. K. V., "the Water Relations and Irrigation Requirements of Passion Fruit (Passiflora Edulis Sims): a Review," Exp. Agric. 49(4), 585-596 (2013).

[47] Reich, P. B., Walters, M. B., Ellsworth, D. S.., Walterst, M. B., "From tropics to tundra : Global convergence in plant functioning," Proc. Natl. Acad. Sci. U. S. A. 94(25), 13730-13734 (1997).

[48] Reich, A. P. B., Wright, I. J., Bares, J. C., Craine, J. M., Oleksyn, J., Westoby, M., Walters, M. B.., Journal, I., "The Evolution of Plant Functional Variation : Traits , Spectra, and Strategies," Int. J. Plant Sci. 164(S3), S143S164 (2003).

[46] Herrera, A., "Crassulacean acid metabolism and fitness under water deficit stress: If not for carbon gain, what is facultative CAM good for?," Ann. Bot. 103(4), 645-653 (2009).

[47] A. Al-Busaidi, T., Yamamoto, T., Tanak, S., Moritani, S., "Evapotranspiration of Succulent Plant ( Sedum" (2013), 17 April 2016, http://cdn.intechopen.com/pdfs-wm/40958.pdf 